\title{
A place in space - the horizontal vs vertical factors that influence zooplankton (Rotifera, Crustacea) communities in a mesotrophic lake
}

\author{
Maciej KARPOWICZ, ${ }^{1 *}$ Jolanta EJSMONT-KARABIN, ${ }^{2}$ Adam WIĘCKO, ${ }^{1}$ Andrzej GÓRNIAK, ${ }^{1}$ Adam CUDOWSKI ${ }^{1}$ \\ ${ }^{1}$ Department of Hydrobiology, Institute of Biology, University of Bialystok, Ciołkowskiego 1J, 15-245 Białystok; ${ }^{2}$ Research Station \\ in Mikolajki, Nencki Institute of Experimental Biology, 3 Pasteur Str., 02-093 Warsaw, Poland
}

\begin{abstract}
The factors that influence plankton distribution in lakes are currently widely debated. The primary objective of this study was to determine a combination of factors that influence the three-dimensional distribution patterns of both rotifer and crustacean communities in a pelagic ecosystem. We compared the abiotic (temperature, oxygen and nutrients) and biotic (phytoplankton) factors that affect the horizontal and vertical distribution of zooplankton in different habitat conditions in Lake Wigry. The results of our study indicate that the vertical gradient in a water profile is much more important for microcrustaceans than horizontal changes in environmental conditions, whereas Rotifera showed a strong spatial autocorrelation when connected with differences in trophic status. Generally, large zooplankton prefer cold, darker waters of the metalimnion-hypolimnion, while smaller zooplankton prefer the warm epilimnion. This niche segregation in water profiles promotes a large diversity of pelagic zooplankton. The vertical distribution of dominant Daphnia cucullata was strongly related to the phytoplankton distribution. Moreover, we found that the large-bodied Daphnia cucullata prefers the lower water layers, despite the presence of less optimal food resources, while smaller individuals clearly prefer the warm surface water with high quality resources.
\end{abstract}

Corresponding author: m.karpowicz@uwb.edu.pl

Key words: Zooplankton spatial distribution, thermocline, Daphnia cucullata, nutrients, phytoplankton.

Edited by: Giampaolo Rossetti, University of Parma, Italy.

Contributions: MK, designed the study, analysed the crustacean zooplankton and water chemistry, undertook field analyses and sampling, performed statistical analysis, and designed and wrote the manuscript; JEK, analysed the Rotifera zooplankton and reviewed the manuscript; $\mathrm{AW}, \mathrm{AG}, \mathrm{AC}$, participated in field analyses and sampling, and analysed the water chemistry.

Conflict of interest: The authors declare no potential conflict of interest.

Funding: This publication has received financial support from the Polish Ministry of Science and Higher Education under subsidy for maintaining the research potential of the Faculty of Biology and Chemistry, University of Bialystok.

Conference presentation: Part of this paper was presented at the $34^{\text {th }}$ Congress of the International Society of Limnology (SIL), 2018 August 19-24, Nanjing, China.

Received: 19 January 2019.

Accepted: 12 June 2019.

This work is licensed under a Creative Commons Attribution NonCommercial 4.0 License (CC BY-NC 4.0).

${ }^{\circ}$ Copyright: the Author(s), 2019

Licensee PAGEPress, Italy

J. Limnol., 2019; 78(2): 243-258

DOI: 10.4081/jlimnol.2019.1886

\section{INTRODUCTION}

Understanding the horizontal and vertical patterns in species abundance and the composition of zooplankton communities is a well-established goal in the ecology of lakes (Whittaker, 1956; Gliwicz, 1980; Cantin et al., 2011). Both abiotic and biotic processes commonly cause lake-wide distributions of plankton to be highly variable and heterogeneous, resulting in considerable patchiness (Folt and Burns, 1999). The spatial distribution of zooplankton in lacustrine environments is affected by multiple physicochemical and biological processes, while their nature and the relative importance vary between ecosystems and spatial and temporal scales (Lampert, 1993; Angeli et al., 1995; Pinel-Alloul, 1995; Bartrons et al., 2015). Dominant factors explaining the large-scale spatial heterogeneity of zooplankton include basin morphology (Pothoven et al., 2004), wind-induced circulation (Lacroix and Lescher-Moutoué, 1995; George and Winfield, 2000; Thackeray et al., 2004), differences in trophic status (Ochocka and Pasztaleniec, 2016) and local eutrophication, e.g. river influxes (Patalas and Salki, 1992; Fietz et al., 2005). As there are a multitude of factors that play a role in structuring the spatial distribution of organisms in lakes, Pinel-Alloul and Ghadouani (2007) promoted a multi-scale perspective on the spatial distribution of plankton communities. They highlighted the abiotic and biotic processes that drive the distribution patterns ranging over both spatial and temporal scales, from millimetres to hundreds of kilometres. Pinel-Alloul (1995) introduced the "multiple 
driving forces hypothesis", stating that neither biotic nor abiotic processes alone can explain the observed spatial distribution patterns. Furthermore, this hypothesis states that the relative importance of such processes is scaledependent: physical processes predominate at large scales, whereas biotic processes predominate at finer scales. For example, George and Winfield (2000) found the lakewide distributions of different zooplankters to be controlled by wind-induced basin-scale currents. However, external wind forces alone were not sufficient to completely explain the distribution patterns, because the vertical depth selection behaviour of the zooplankters, i.e. biotic processes, determined their vertical position and, as such, the direction in which the respective current acted upon. Many planktonic organisms have the ability to move between habitats (either horizontally or vertically) in search of favourable abiotic (i.e. water temperature, nutrients) and biotic (i.e. high food resources, a refuge from predators) conditions (Rosenzweig, 1991; Brown, 1990; Lima, 1998).

On a smaller scale, the vertical gradient of environment conditions strongly influences plankton communities (Karpowicz and Ejsmont-Karabin, 2017; Sługocki and Czerniawski, 2018). A sharp temperature gradient in the metalimnion results in an increased water density and viscosity, which decreases the sinking speed of falling particles. These nutrient-rich waters of the metalimnion play an important potential role in the functioning of phytoplankton in low trophic lakes, where nutrient depletion often occurs in the epilimnion during thermal stratification (Gliwicz, 1979; Cantin et al., 2011). This depletion causes an absolute maximum of chlorophyll $a$ concentration in the vertical profile to be located in deep layers of stratified lakes. This high chlorophyll $a$ layer is a very important food source for large zooplankton such as Daphnia spp. There is clear evidence that food resources for zooplankton in deep-water layers (DWL) are as profitable as those from upper layers (Winder et al., 2003), while these resources are much more abundant in the DWL. The quality of these food resources has been reported to be lower in the DWL (Cole et al., 2002); however, not all studies confirmed that (Winder et al., 2003). The cold and dark waters of the metalimnion-hypolimnion are also an ideal daytime refuge for large species, such as Daphnia spp., which are highly vulnerable to predation by fish (Brooks and Dodson, 1965). Lampert and Grey (2003) suggested that filter-feeding Daphnia, in that particular case, will lead to distribution according to an Ideal Free Distribution with Costs model (Tyler and Gilliam, 1995), optimising their fitness in response to food and temperature conditions. The migration of large zooplankton to deeper waters creates favourable conditions for smaller species in the epilimnion (Karpowicz and Ejsmont-Karabin, 2017). Different groups of zooplankton are regulated by different combinations of environmental factors. For example, Rotifera and small Cladocera are mainly regulated by "bottom-up" forces (Ejsmont-Karabin, 2012). Furthermore, an increase in rotifer density with increasing trophic status has been extensively reported (Bays and Crisman, 1983; Pace, 1986; Yoshida et al., 2003). Rotifers can also be effectively depressed by crustacean zooplankton through mechanical interference, exploitative competition and predation. Many studies have revealed the inverse relationship between the densities of crustaceans and rotifers in natural environments (Fussmann, 1996; Gilbert, $1985,1989)$. On the other hand, large zooplankton are mainly regulated by 'top-down' forces (fish predation); however, they could be susceptible to the negative influence of filamentous algae blooms (Gliwicz, 1990) and the toxic influence of cyanoprokaryotes (Ferrão-Filho and Kozlowsky-Suzuki, 2011).

Previous findings suggest that some zooplankton groups are influenced by vertical gradients, while others can show strong horizontal autocorrelation. The description of patterns of zooplankton abundance in lakes has usually taken one of two approaches: either through determining the relative importance of spatial and temporal components of heterogeneity or through exclusively concentrating on vertical gradients. This study brings together these two approaches to better understand the heterogeneity of pelagic zooplankton in lakes. Therefore, the main aim of this research is to determine a combination of factors that influence the threedimensional distribution patterns of rotifer and crustacean communities in a pelagic ecosystem. In this study, we compared the abiotic (temperature, oxygen, nutrients) and biotic (phytoplankton) factors that affect the horizontal and vertical distribution of zooplankton in different habitat conditions within one lake. Lake Wigry provides the opportunity to conduct this research because of its diversified coastline and morphometry, which leads to a unique habitat, particularly with regards to trophic, thermal, oxygen and water exchange conditions (Kamiński, 1999). Here, we hypothesised that trophic status is important on larger scales, affecting the distribution patterns of zooplankton over the whole system, whereas ecological processes (e.g. competition, predation) are more relevant on local scales.

Additionally, the zooplankton of Lake Wigry feature a large variety of Cladocera and the occurrence of many genera from this group, as well as the co-occurrence of a few species of the same genus, especially Daphnia, where 3-5 species were found at one station (Karabin and Ejsmont-Karabin, 1992; Karpowicz and Górniak, 2013). Fish communities in Lake Wigry are strongly dominated by planktivorous fish; however, large-bodied zooplankton (Daphnia spp.) still dominate. It will be interesting to understand the factors that promote high densities of large 
species despite the high fish predation (Kamiński, 1999). Until now, the mechanisms of niche segregation (habitat and food) of the large zooplankton species and its impact on small zooplankton have not been elucidated. Therefore, the second aim of this study is to identify the combination of abiotic and biotic factors that promote niche segregation by the zooplankton species in the vertical profiles and promote their large diversity. This information on the simultaneous distribution of organisms at different trophic levels within the food web, together with physical and chemical information, constitute the basic material for modelling a pelagic ecosystem (Carpenter, 1988; Pace et al., 1999; Jeppesen et al., 2005) and is essential for a comprehensive understanding of the functioning of lake ecosystems (Rinke et al., 2009).

\section{Study sites}

Lake Wigry is one of the largest (area: $21.7 \mathrm{~km}^{2}$ ) and deepest (max depth: $73 \mathrm{~m}$; average depth: $15.4 \mathrm{~m}$ ) lakes in north-eastern Poland. Lake Wigry and its adjacent area belong to the Wigry National Park, which is situated in the Augustów Primeval Forest, where trees grow on about $80 \%$ of its shoreline. Lake Wigry is mainly supplied by the Czarna Hańcza River, which flows into the lake via its northern basin. The waters are also fed by some smaller streams, as well as groundwater and precipitation. The ichthyofauna of Lake Wigry includes 32 species and the fish structure is dominated by several planktivorous species: Coregonus lavaretus, Coregonus albula, Osmerus eperlanus, and Salmo trutta m. lacustris (Kamiński, 1999). The park actively protects its ichthyofauna by increasing the number of predatory fish, reducing the number of cyprinid fish, maintaining the species diversity, restoring extinct species (brown lake trout Salmo trutta) or increasing the populations of threatened species (such as wels Silurus glanis). An additional attribute of the lake includes the presence of cold-stenotherm arctic zooplankton species, which are typical of low trophic lakes: Daphnia longiremis, Eurytemora lacustris, and Heterocope appendiculata (Karpowicz and Górniak, 2013).

Lake Wigry is unusual due to its diversified morphometry (Fig. 1). The shape of the lake and its bathymetry are conducive to diverse habitat conditions, in particular with respect to trophic, thermal and oxygen conditions, as well as water exchange. The lake therefore provides an excellent opportunity to conduct research into the response of plankton species and communities to different habitat conditions within one lake (Kamiński, 1999). The unique variety and diversity of habitats in Lake Wigry means that our results are applicable to lakes with different trophic statuses. Due to its diversity, Lake Wigry was adopted by the International Association of Theoretical and Applied Limnology in 1998 (Kamiński, 1999).

In our study, station I represents many isolated bays with higher trophic status, while stations II and III represent deep mesotrophic basins (Fig. 1). Station II is located in the North Basin, with a maximum depth of 56 $\mathrm{m}$; this part of the lake was heavily polluted in the 1970s by the Czarna Hańcza River, which receives sewage from the nearby city of Suwałki, with a population of approximately 70,000. However, in recent years, there was an improvement in the trophic status of this part of the lake (Karpowicz and Górniak, 2013). Station III is located in the deepest part of the lake (Tab. 1), which,

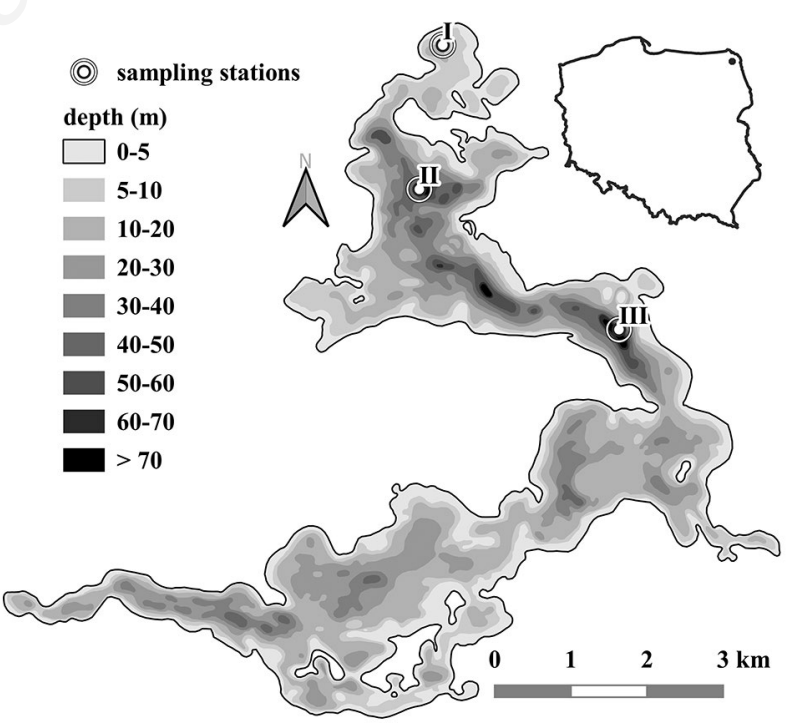

Fig. 1. Bathymetric map of Lake Wigry with the locations of the sampling stations.

Tab. 1. Characteristics of the sampling stations in Lake Wigry.

\begin{tabular}{|c|c|c|c|c|c|c|}
\hline Sampling station & Name & Latitude & Longitude & Max depth (m) & SDV 2015 (m) & SDV 2016 (m) \\
\hline I & Zadworze Bay & $54^{\circ} 04^{\prime} 42.01^{\prime \prime} \mathrm{N}$ & $23^{\circ} 05^{\prime} 19.08^{\prime \prime} \mathrm{E}$ & 20 & 2.65 & 4.9 \\
\hline II & North Basin & $54^{\circ} 03^{\prime} 34.56^{\prime \prime} \mathrm{N}$ & $23^{\circ} 04^{\prime} 44.04^{\prime \prime} \mathrm{E}$ & 56 & 2 & 3.5 \\
\hline III & Central Basin & $54^{\circ} 02^{\prime} 36.96^{\prime \prime} \mathrm{N}$ & $23^{\circ} 07^{\prime} 14.16^{\prime \prime} \mathrm{E}$ & 74 & 2.2 & 3.2 \\
\hline
\end{tabular}

$\overline{S D V}$, Secchi disc visibility. 
based on long-term data, is characterised by the lowest trophic conditions of the lake (Kamiński, 1999).

\section{METHODS}

The study was conducted in the summer stagnation of 2015 (07.08.2015) and $2016(26.07 .2016)$ in the three parts of Lake Wigry, with various environmental conditions. The sampling stations were located close to the deepest point within each station. The samples were collected in the middle of the day from 11:00 to 13:00, from three sampling stations (Tab. 1). The field measurements included Secchi disc visibility (SDV), conductivity (EC) and the concentration of dissolved oxygen, which was measured using an HQ40D Multi Meter (Hach-Lange GmbH, Dusseldorf, Germany). Phytoplankton communities and temperature were both measured in situ by the submersible spectrofluorometer Fluoroprobe (bbe-Moldaenke GmbH, Schwentinental, Germany). This probe is a commonly used profiling instrument that measures fluorescence emission at $\sim 680$ $\mathrm{nm}$ in response to excitation by light emitting diodes (LEDs), centred at approximately $370,470,525,570,590$ and $610 \mathrm{~nm}$ (Harrison et al., 2016). The Fluoroprobe estimates chlorophyll a concentrations for four phytoplankton groups based on their fluorescence excitation spectra: (GI) Chlorophyta and Euglenophyta (chlorophylls $a$ and $b$ ); (GII) Heterokontophyta, Haptophyta and Dinophyta (chlorophylls $a$ and $c$ and fucoxanthin-peridinin); (GIII) Cryptophyta (chlorophylls $a$ and $c$ and phycobilins); and (GIV) Cyanophyta (chlorophyll $a$ and phycobilins). The default norm spectra for each Fluoroprobe unit, provided by the manufacturer, are determined by measuring the fluorescence excitation spectra of laboratory cultures (of a known chl- $a$ concentration) of phytoplankton species, representative of the major pigment groups (Beutler et al., 2002). The bbe FluoroProbe, with additional transmission sensors, provides automatic corrections for chromophoric dissolved organic matter (CDOM) and turbidity. Continuous measurements represent a large advantage over discrete sampling, since some species of phytoplankton (e.g. cyanobacteria) can be concentrated in a very thin layer (Gregor and Marsálek, 2003). Field measurements of temperature, oxygen, conductivity and phytoplankton were made from the surface to 30 metres.

The water samples for chemical analyses and zooplankton samples were collected every metre from the surface to a depth of 10 metres with the 5-L Limnos sampler. Additionally, in 2016, samples were collected from depths of 11 metres (upper hypolimnion) and 30 metres (middle of hypolimnion). For zooplankton samples, five litres of water from each meter was filtered through a $50 \mu \mathrm{m}$ plankton net and fixed with $4 \%$ formalin.
The crustaceans and rotifers were determined to the species level and counted in the whole samples. Additionally, 10 length measurements were made for each crustacean species (Karpowicz and Ejsmont-Karabin, 2017). The mean animal lengths were used to estimate the biomass of planktonic crustaceans; this estimate was achieved by applying the equations used by Błędzki and Rybak (2016). The biomass of rotifers was established following Ejsmont-Karabin (1998).

The analyses of the chemical parameters of water were performed immediately in the laboratory. The concentrations of ions $\left(\mathrm{PO}_{4}{ }^{3-}, \mathrm{NH}_{4}{ }^{+}\right.$, and $\left.\mathrm{NO}_{3}{ }^{-}\right)$were determined in a Dionex ICS 1100 ion chromatograph based on Standard Methods (APHA, 2001). The concentrations of total nitrogen (TN), total organic carbon (TOC), dissolved organic carbon (DOC) and inorganic carbon (IC) were analysed via high-temperature catalytic combustion using a Shimadzu TOC-L Series. Particulate organic carbon (POC) was calculated as the differences between TOC and DOC (Karpowicz and Ejsmont-Karabin, 2018).

The simple relationship between the two variables was examined using a Spearman rank-correlation. To test which chemical parameters differ according to vertical (epilimnion and metalimnion), horizontal (stations I, II, III) and temporal (2015 vs 2016) gradients, we used oneway ANOVA followed by Tukey (HSD) multiple comparisons. By using separate linear regressions for each parameter, we determined which variables provide significant information to the model. To evaluate the summary effect of environmental variables (abiotic and biotic) on the zooplankton communities, canonical correspondence analysis (CCA) was performed on data from both years and all three stations. For this analysis, only the dominant Rotifera and Crustacea species, with frequencies greater than $50 \%$, were selected. The canonical correspondence analysis is a very useful tool for ecologists to relate the abundance of species to many environmental variables (ter Braak, 1986). However, to identify a combination of environmental factors that promote niche segregation by the four species of Daphnia in the vertical profiles, we used an analysis of covariance (ANCOVA) with the Type III SS (Sum of Squares).

The similarity of Crustacea and Rotifera assemblages in the vertical and horizontal gradient was presented by the agglomerative hierarchical classification (AHC) based on the Bray-Curtis matrix. The Mantel test (with 10000 permutations) was performed on the on Bray-Curtis matrices obtained in 2015 and 2016 to determine whether Crustacea and Rotifera show significant concordance in their community composition between the two years. The correlation coefficient (Mantel r) was used as an indicator of temporal variation (Korhonen et al., 2013). The statistical analyses were performed with XLSTATEcology (Addinsoft). 


\section{RESULTS}

\section{Environmental conditions}

The analysis of variance results showed that most of the hydrochemical parameters provide significant information to the model. Only the concentrations of TOC and POC did not provide any significant information and were therefore excluded from the subsequent analysis (Tab. 2). Our analysis revealed significant differences between the environmental conditions in three gradients (vertical, horizontal, and temporal). The most important was the vertical gradient, which significantly influenced most of the hydrochemical parameters (Tab. 2). Only the concentration of $\mathrm{NH}_{4}^{+}$was not affected by the metalimnetic gradient (Tabs. 2 and 3). The thermocline was typically at a depth of 7-10 metres (Fig. 2). Additionally, the highest concentrations of oxygen were observed in the upper epilimnion at a depth of 2 metres. Also, a decrease in oxygen concentrations was observed, with the lowest concentrations being found in the metalimnion (Fig. 2). However, a well-oxygenated hypolimnion indicates a good ecological state of the lake (Fig. 2). Reduced sinking rates of particulates or animals with increasing water density may result in accumulating them in the metalimnion. The oxidative consumption of oxygen associated with microbial

Tab. 2. Results of one-way ANOVA followed by Tukey (HSD) multiple comparisons between the water chemistry in vertical gradient (epilimnion $v s$ metalimnion), horizontal gradient (station I, II, III) and time (2015 vs 2016).

\begin{tabular}{|c|c|c|c|c|c|c|c|c|c|c|c|c|}
\hline \multirow[t]{3}{*}{ Variables } & \multicolumn{2}{|c|}{ ANOVA } & \multicolumn{6}{|c|}{ Turkey HSD } & & & & \\
\hline & \multirow[t]{2}{*}{$\mathbf{F}$} & \multirow[t]{2}{*}{$\mathbf{P}$} & \multicolumn{2}{|c|}{ Epi us meta } & \multicolumn{2}{|c|}{2015 vs 2016} & \multicolumn{2}{|c|}{ I vs II } & \multicolumn{2}{|c|}{ II vs III } & \multicolumn{2}{|c|}{ I vs III } \\
\hline & & & std.diff & $\mathbf{P}$ & std.diff & $\mathbf{P}$ & std.diff & $\mathbf{P}$ & std.diff & $\mathbf{P}$ & std.diff & $\mathbf{P}$ \\
\hline Temp & 43.2 & $* * *$ & 12.85 & $* * *$ & 1.77 & ns & 0.5 & ns & 0.02 & ns & 0.48 & ns \\
\hline $\mathrm{O}_{2}$ & 46.12 & $* * *$ & 12.28 & $* * *$ & 1.33 & ns & 3.35 & $* *$ & 0.05 & ns & 3.3 & $*$ \\
\hline $\mathrm{EC}$ & 38.1 & $* * *$ & 10.47 & $* * *$ & 3.12 & $*$ & 2.94 & $*$ & 1.58 & $\mathrm{~ns}$ & 4.44 & $* * *$ \\
\hline $\mathrm{NH}_{4}^{-}$ & 12.52 & $* * *$ & 1.05 & ns & 5.62 & $* * *$ & 1.67 & $\mathrm{~ns}$ & 2.78 & $*$ & 4.3 & $* * *$ \\
\hline $\mathrm{NO}_{3}^{-}$ & 6.62 & $* *$ & 4.36 & $* * *$ & 0.07 & ns & 3.29 & $* *$ & 0.93 & ns & 2.4 & $*$ \\
\hline $\mathrm{PO}_{4}^{3-}$ & 4.38 & $* *$ & 0.1 & $*$ & 0.006 & ns & 2.73 & $*$ & 1.05 & $\mathrm{~ns}$ & 1.74 & ns \\
\hline TOC & 2.31 & ns & 1.13 & $\mathrm{~ns}$ & 1.93 & $\mathrm{~ns}$ & 0.5 & $\mathrm{~ns}$ & 1.6 & $\mathrm{~ns}$ & 1.02 & $\mathrm{~ns}$ \\
\hline DOC & 16.05 & $* * *$ & 7.44 & $* * *$ & 0.78 & $\mathrm{~ns}$ & 1.83 & ns & 2 & $\mathrm{~ns}$ & 3.74 & $* *$ \\
\hline POC & 2.05 & ns & 0.94 & ns & 2.01 & ns & 1.11 & ns & 1.22 & ns & 0.04 & ns \\
\hline $\mathrm{IC}$ & 54.12 & $* * *$ & 9.66 & $* * *$ & 4.43 & $* * *$ & 5.39 & $* * *$ & 2.72 & $*$ & 7.97 & $* * *$ \\
\hline $\mathrm{TN}$ & 12.96 & $* * *$ & 5.8 & $* * *$ & 1.89 & $\mathrm{~ns}$ & 1.16 & $\mathrm{~ns}$ & 1.64 & ns & 2.71 & $*$ \\
\hline $\mathrm{DN}$ & 12.63 & $* * *$ & 5.5 & $* * *$ & 2.53 & ns & 1.58 & $\mathrm{~ns}$ & 1.7 & $\mathrm{~ns}$ & 3.2 & $* *$ \\
\hline
\end{tabular}

Epi, epilimnion; meta, metalimnion; std.diff, standardized mean difference; * $P \leq 0.05$; ** $P \leq 0.001 ; * * * P \leq 0.0001 ; n s, P>0.05$.

Tab. 3. Average concentration $( \pm \mathrm{SD})$ of nutrients in the water column of sampling stations.

\begin{tabular}{|c|c|c|c|c|c|c|c|c|}
\hline Year & Station & & $\mathrm{TN}\left(\mathrm{mg} \mathrm{L}^{-1}\right)$ & $\mathrm{NH}_{4}^{+}\left(\mathrm{mg} \mathrm{L}^{-1}\right)$ & $\mathrm{NO}_{3}^{-}\left(\mathrm{mg} \mathrm{L}^{-1}\right)$ & $\mathrm{PO}_{4}{ }^{3-}\left(\mathrm{mg} \mathrm{L}^{-1}\right)$ & $\mathrm{DOC}\left(\mathrm{mg} \mathrm{L}^{-1}\right)$ & $\mathrm{IC}\left(\mathrm{mg} \mathrm{L}^{-1}\right)$ \\
\hline \multirow{6}{*}{2015} & I & $\mathrm{E}$ & $0.44 \pm 0.03$ & $0.21 \pm 0.02$ & $0.04 \pm 0.02$ & $0.12 \pm 0.05$ & $5.39 \pm 0.35$ & $28.04 \pm 0.7$ \\
\hline & & M & $1.08 \pm 0.04$ & $0.29 \pm 0.01$ & $0.03 \pm 0.01$ & $0.08 \pm 0.09$ & $4.45 \pm 0.1$ & $33.47 \pm 0.24$ \\
\hline & II & $\mathrm{E}$ & $0.49 \pm 0.04$ & $0.22 \pm 0.07$ & $0.08 \pm 0.05$ & $0.07 \pm 0.04$ & $5.11 \pm 0.16$ & $25.90 \pm 1.71$ \\
\hline & & M & $0.64 \pm 0.02$ & $0.23 \pm 0.05$ & $0.27 \pm 0.02$ & $0.10 \pm 0.01$ & $4.92 \pm 0.44$ & $30.35 \pm 0.08$ \\
\hline & III & $\mathrm{E}$ & $0.44 \pm 0.02$ & $0.16 \pm 0.03$ & $0.05 \pm 0.03$ & $0.10 \pm 0.05$ & $4.88 \pm 0.58$ & $25.24 \pm 1.13$ \\
\hline & & M & $0.59 \pm 0.05$ & $0.18 \pm 0.02$ & $0.22 \pm 0.13$ & $0.14 \pm 0.02$ & $4.46 \pm 0.37$ & $29.01 \pm 0.16$ \\
\hline \multirow[t]{9}{*}{2016} & I & $\mathrm{E}$ & $0.60 \pm 0.03$ & $0.15 \pm 0.03$ & $0.03 \pm 0.01$ & $0.02 \pm 0.01$ & $5.29 \pm 0.2$ & $31.14 \pm 0.79$ \\
\hline & & M & $0.66 \pm 0.1$ & $0.17 \pm 0.07$ & $0.03 \pm 0.01$ & $0.60 \pm 0.19$ & $4.75 \pm 0.28$ & $33.40 \pm 2.08$ \\
\hline & & $\mathrm{H}$ & 1.01 & 0.37 & 0.02 & 0.20 & 4.50 & 37.19 \\
\hline & II & $\mathrm{E}$ & $0.59 \pm 0.05$ & $0.15 \pm 0.04$ & $0.02 \pm 0.01$ & $0.02 \pm 0.01$ & $5.08 \pm 0.12$ & $28.07 \pm 1.96$ \\
\hline & & M & $0.78 \pm 0.05$ & $0.13 \pm 0.01$ & $0.38 \pm 0.42$ & $0.02 \pm 0.01$ & $4.30 \pm 0.08$ & $31.52 \pm 0.36$ \\
\hline & & $\mathrm{H}$ & 0.75 & 0.10 & 0.11 & 0.02 & 4.48 & 29.40 \\
\hline & III & $\mathrm{E}$ & $0.53 \pm 0.02$ & $0.12 \pm 0.02$ & $0.03 \pm 0.02$ & $0.02 \pm 0.01$ & $5.02 \pm 0.08$ & $25.69 \pm 0.33$ \\
\hline & & M & $0.65 \pm 0.11$ & $0.11 \pm 0.01$ & $0.20 \pm 0.17$ & $0.14 \pm 0.16$ & $4.33 \pm 0.23$ & $30.22 \pm 1.61$ \\
\hline & & $\mathrm{H}$ & 0.84 & 0.13 & 0.09 & 0.02 & 4.15 & 32.80 \\
\hline
\end{tabular}

E, epilimnion (0-6 m); M, metalimnion (7-10 m); H, hypolimnion (30 m); TN, total nitrogen; DOC, dissolved organic carbon; IC, inorganic carbon. 
respiration and animal respiration results in a metalimnetic oxygen minimum. Decreasing sinking rates result in a significant increase of dissolved substances in the water, expressed as electrical conductivity (Fig. 3). In the metalimnion, concentrations of $\mathrm{TN}$ and $\mathrm{IC}$ were also significantly higher (Tabs. 2 and 3). In the horizontal gradient, there were significant differences in the hydrochemistry between the shallow bay (station I) and the two-deep basins (stations II and III) (Tab. 2). The oxygen profiles of station I were clinograde curves, with strong anoxia close to the bottom, while there were negative heterograde curves in stations II and III (Fig. 2). However, the highest water transparency for both years was seen in station I (Tab. 1). Station II differed from station III in concentrations of $\mathrm{NH}_{4}^{+}$and IC (Tab. 2). There were also differences in the environmental conditions between 2015 and 2016; lower water transparency was observed in 2015 (Tab. 1), as well as notable differences in $\mathrm{NH}_{4}^{+}, \mathrm{IC}$ and EC concentrations (Tab. 2).

\section{Distribution of phytoplankton}

The total chlorophyll concentrations in stations II and III did not exceed $20 \mu \mathrm{g} \mathrm{L}{ }^{-1}$, while chl- $a$ concentrations reached almost $60 \mu \mathrm{g} \mathrm{L}^{-1}$ in station I (Fig. 4). The higher total phytoplankton concentrations were observed in 2015 in stations I and III. The maximum concentration of phytoplankton in deep basins (station II, III) was found in the lower epilimnion, while a maximum concentration of phytoplankton was observed close to the bottom in station I (Fig. 4). The phytoplankton of Lake Wigry was dominated by two groups: GIII - Cryptophyta and GII Heterokontophyta, Haptophyta and Dinophyta. Generally, Cryptophyta dominated in the metalimnion, while GII was the most important component of phytoplankton in the epilimnion. Chlorophyta and Euglenophyta were present only in the upper water layer, with a maximum concentration at 0-2 m. Cyanophyta were present below the epilimnion zone (Fig. 4).

\section{Distribution of crustacean zooplankton}

The crustacean biomass ranged from 0.17 to $11.36 \mathrm{mg}$ $\mathrm{L}^{-1}$ and there were large differences in the vertical distribution of Crustacea. The highest crustacean zooplankton biomass was found in the epilimnion zone, with the exception of that found between the surface layer and $1 \mathrm{~m}$. A high zooplankton biomass was also found in the upper metalimnion (Fig. 4). The dominant species was D. cucullata, reaching up to $80 \%$ of the total crustacean biomass in 2015 (Fig. 4). The biomass of D. cucullata in the water profile was similar to the vertical distribution of the total phytoplankton biomass (Fig. 4). The highest abundance of D. cucullata was found in the middle of the epilimnion, with an abundance exceeding 100 ind. $\mathrm{L}^{-1}$
(Fig. 5). However, there were differences in body size and the abundance of D. cucullata in vertical profiles. The highest number of $D$. cucullata with smaller body sizes $(913 \pm 208 \mu \mathrm{m})$ was found in the epilimnion zones, while low abundance and larger body size $(1160 \pm 181 \mu \mathrm{m})$ was recorded in the metalimnion zones (Fig. 5). In particular, the youngest Daphnia prefer surface water up to a depth of $3 \mathrm{~m}$ (Fig. 5). Additionally, we observed the cooccurrence of 3-4 Daphnia species in all sampling stations. The higher share of Daphnia cristata and D. longispina was observed in the metalimnion (Fig. 4), while $D$. longiremis and $D$. hyalina were more frequently found in the hypolimnion. The cold waters of hypolimnion and lower metalimnion were preferred by Eurytemora lacustris (Fig. 4).

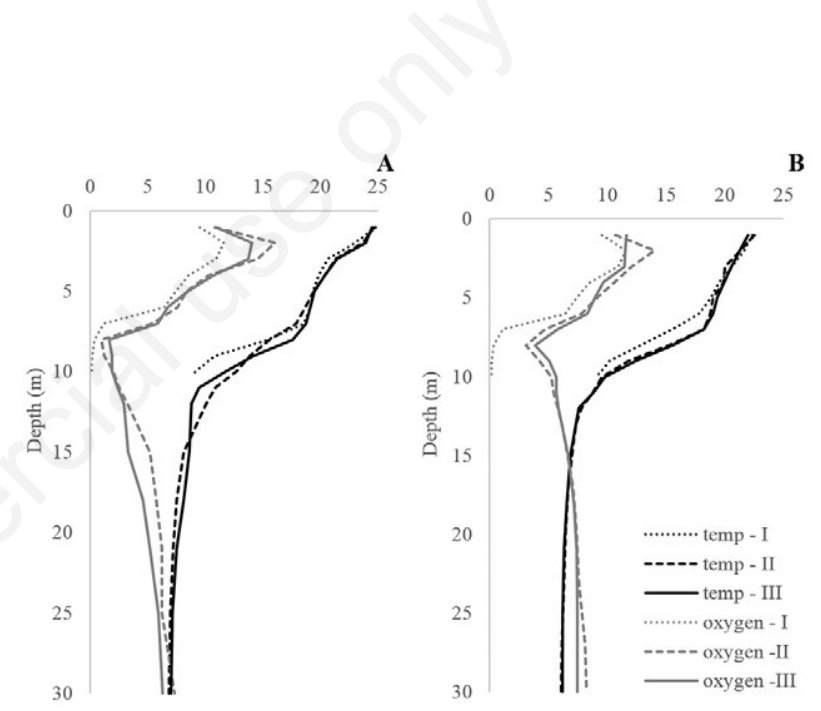

Fig. 2. Vertical gradients of temperature $\left({ }^{\circ} \mathrm{C}\right)$ - black lines, and oxygen concentration $\left(\mathrm{mg} \mathrm{O}_{2} \mathrm{~L}^{-1}\right)$ - grey lines in three parts of Lake Wigry in 2015 and 2016.

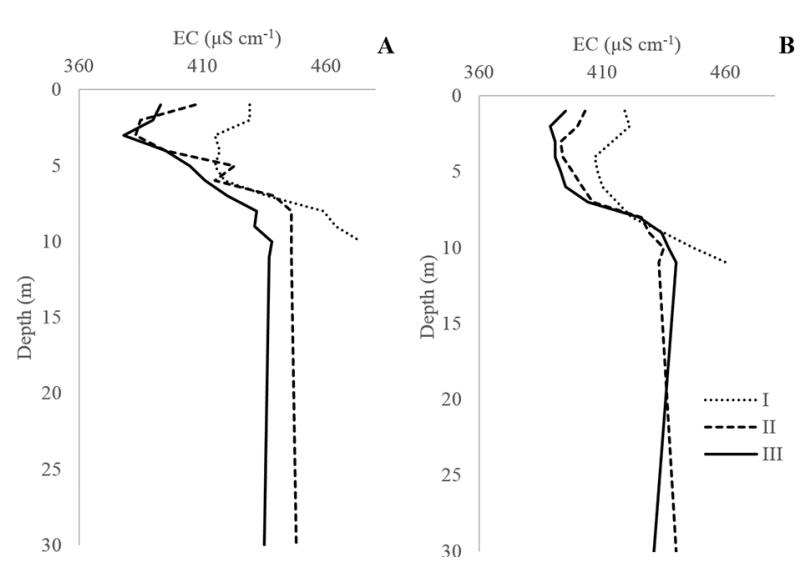

Fig. 3. Vertical gradients of electrical conductivity $\left(\mu \mathrm{S} \mathrm{cm}^{-1}\right)$ in three parts of Lake Wigry in 2015 and 2016. 

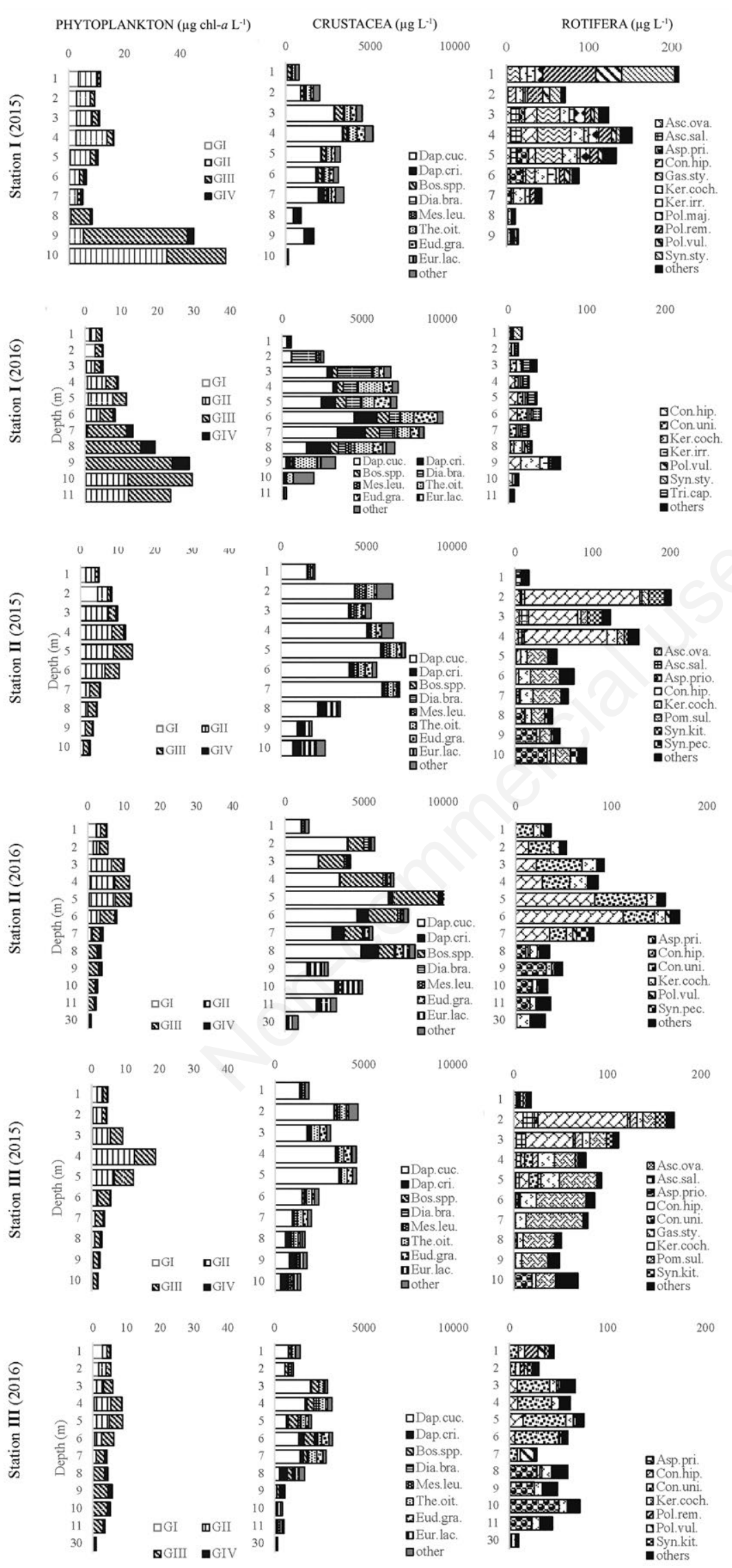

Fig. 4. Vertical distribution of phytoplankton communities ( $\mu \mathrm{g}$ chl- $a \mathrm{~L}^{-1}$ ), dominant crustacean species $\left(\mu \mathrm{g} \mathrm{L}^{-1}\right)$ and dominant Rotifera species $\left(\mu \mathrm{g} \mathrm{L^{-1 }}\right)$. Abbreviations phytoplankton: GI - Chlorophyta and Euglenophyta; GII - Heterokontophyta Haptophyta and Dinophyta; GIII Cryptophyta; GIV - Cyanophyta. Abbreviations Crustacea: Dap.cuc. - Daphnia cucullata; Dap.cri. - Daphnia cristata; Dia.bra. - Diaphanosoma brachyurum; Bos.spp. - Bosmina species; Eud.gra. Eudiaptomus graciloides; Eur.lac. Eurytemora lacustris; The.oit. Thermocyclops oithonoides; Mes.leu. Mesocyclops leuckarti. Abbreviations Rotifera: Asc.ova. - Ascomorpha ovalis; Asc.sal. - Ascomorpha saltans; Asp.pri. Asplanchna priodonta; Con.hip. - Conochilus hippocrepis; Con.uni. - Conochilus unicornis; Gas.sty. - Gastropus stylifer; Ker.coch. Keratella cochlearis; Ker.irr. - Keratella irregularis; Pol.maj. - Polyarthra major; Pol.rem. - Polyarthra remata; Pol.vul. Polyarthra vulgaris; Pom.sul. - Pompholyx sulcate; Syn.sty. - Synchaeta stylata; Syn.kit. - Synchaeta kitina; Syn.pec. - Synchaeta pectinata; Tri.cap. - Trichocerca capucina. 
In the epilimnion zone, apart from D. cucullata, Bosmina crassicornis, Bosmina berolinensis, Diaphanosoma brachyurum and Eudiaptomus graciloides were also found. The level of these species in the zooplankton biomass was higher in 2016. Generally, there was a small amount of Cyclopoida in the total crustacean biomass, indicating a low trophic status. However, we observed differences in the horizontal abundance of some species. A greater share of Diaphanosoma brachyurum, Thermocyclops oithonoides and Mesocyclops leuckarti was observed in station I, whereas Eurytemora lacustris, Bosmina crassicornis and Bosmina berolinensis had higher representation in station II for both years (Fig. 4). Generally, a higher crustacean biomass was observed in 2016 in stations I and II. The lowest zooplankton biomass was at station III in both years. Despite the differences in the zooplankton biomass between years and sampling stations, the vertical distribution of dominant crustaceans was similar for both years (Fig. 4 and Fig. 6).

\section{Distribution of rotifer zooplankton}

The total biomass of rotifers was very low, never exceeding $0.2 \mathrm{mg} \mathrm{L}^{-1}$. It was different between the two years of the study and between the studied stations. The highest year to year differences were observed at the shallow bay (a station I), where the maximum biomass of Rotifera was found at a depth of $1 \mathrm{~m}$ in $2015(0.21 \mathrm{mg}$ $\left.\mathrm{L}^{-1}\right)$ and at a depth of $9 \mathrm{~m}$ in $2016\left(0.07 \mathrm{mg} \mathrm{L}^{-1}\right)$. The difference in the biomass of Rotifera at the two-deep stations was less distinct; the maximum biomass was noted in the epilimnion, but at different depths (Fig. 4). In general, the distribution of the rotifer biomass did not correspond to the biomass of phytoplankton at stations I and III, and was

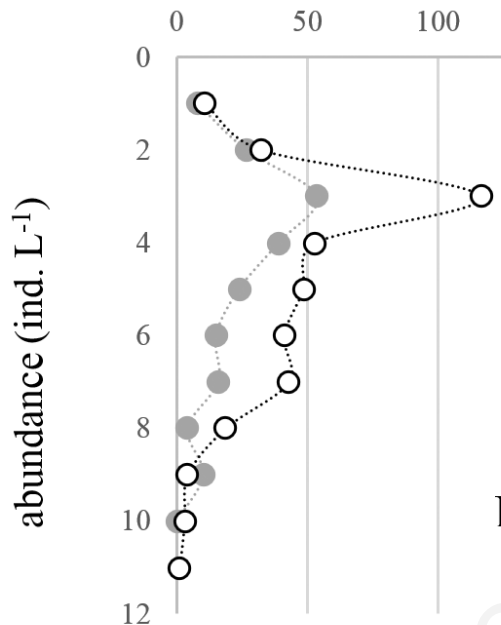

150
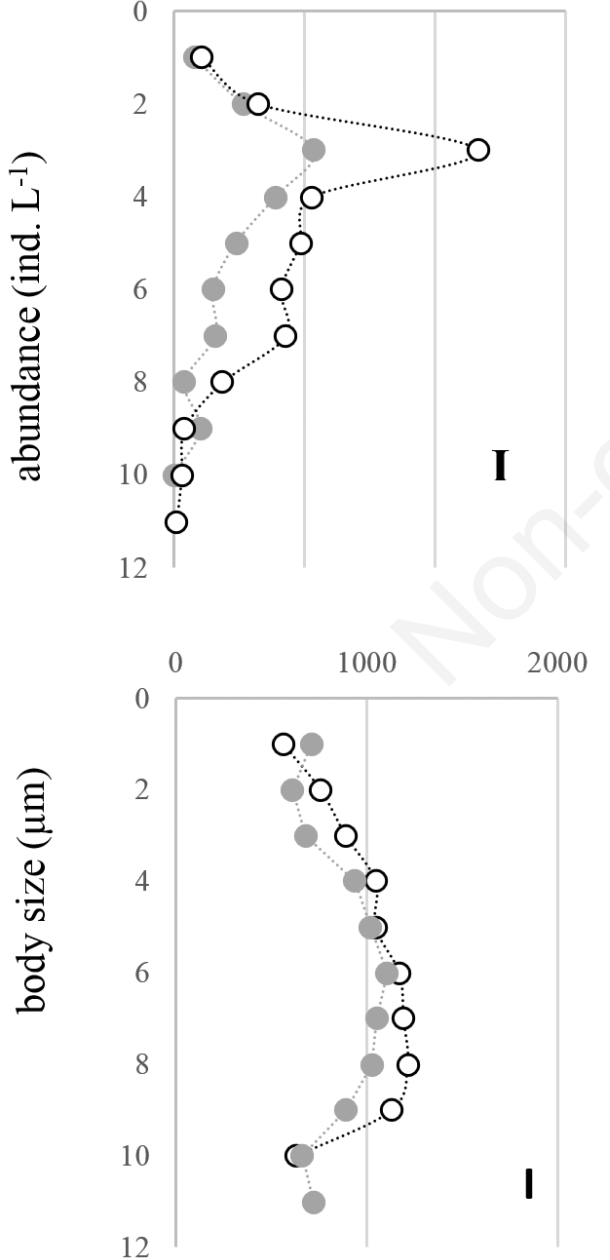
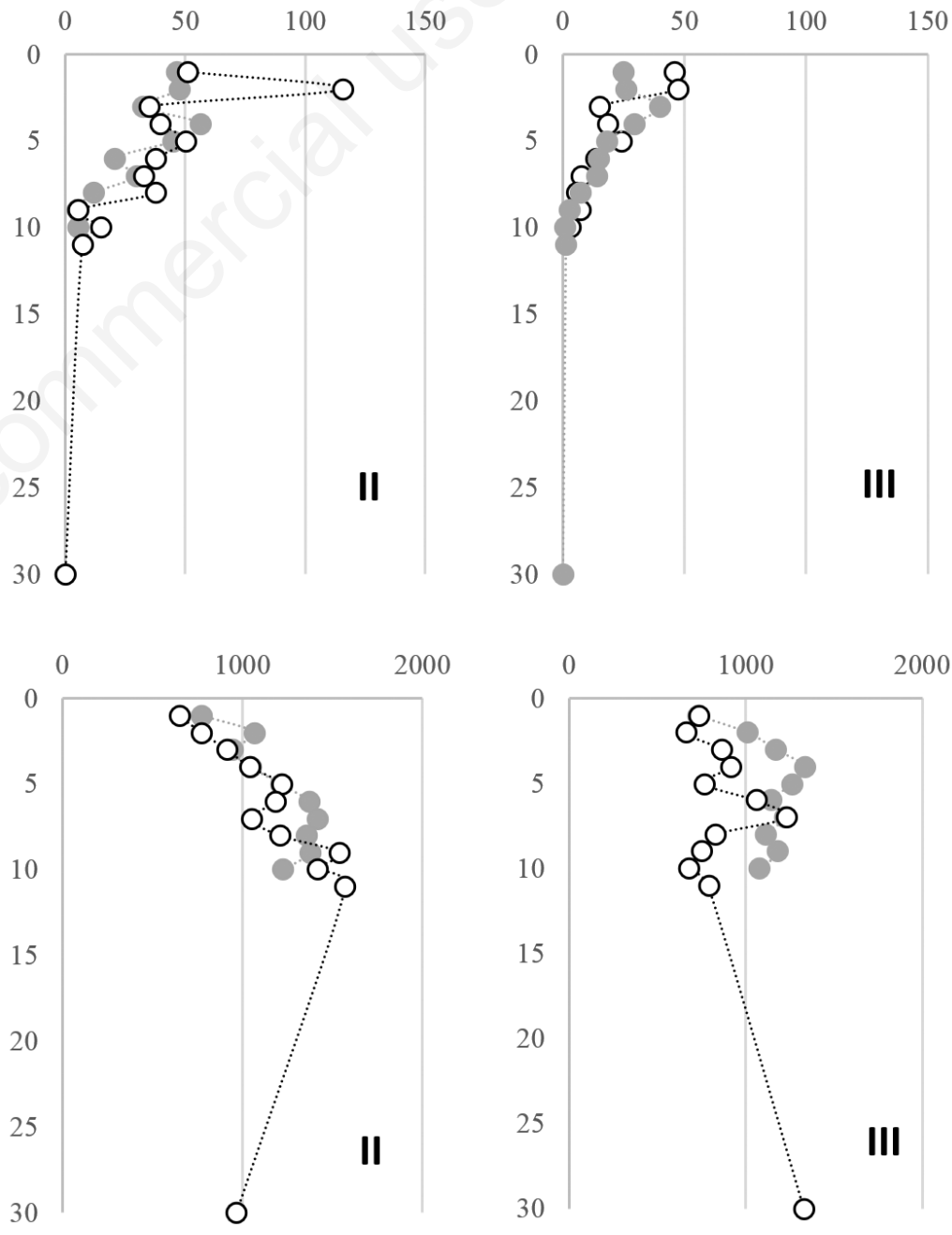

Fig. 5. Vertical distribution (ind. $\mathrm{L}^{-1}$ ) and average body size $(\mu \mathrm{m})$ of $D$. cucullata. Grey dots represented 2015, and white dots represented 2016. 
similar at station II. The vertical distribution of the rotifer biomass was closer to the distribution of Crustacea biomass. However, some differences were observed with regards to the biomass of those zooplankton groups in the upper part of the epilimnion.

At the two deep stations, the dominant species was the colonial Conochilus hippocrepis, which is typical for mesotrophic waters. In 2016, this species was accompanied by another colonial species of the same genus, Conochilus unicornis. Both of these species comprised approximately $85 \%$ and $57 \%$ of the total rotifer biomass in 2015 and 2016, respectively (Fig. 4). The distribution of the species was similar to the vertical distribution of phytoplankton and crustaceans. In both years, the biomass of both the dominant and the remaining species was extremely low at a depth of $1 \mathrm{~m}$ and much higher at depths of between 2 and $4 \mathrm{~m}$. In deep epilimnion and metalimnion realms, a species typical of eutrophic waters, Pompholyx sulcata, became dominant. However, a different situation was observed at the shallow station I in 2015. There, the species structure of that rotifer community was completely different at a depth of $1 \mathrm{~m}$, where species of the genus Polyarthra dominated, than in the deeper parts of epilimnion, where Gastropus stylifer and C. hippocrepis dominated. The biomass of the large, predatory Asplanchna priodonta became dominant in the lower metalimnion region at the two deep stations (Fig. 4).

\section{Environmental factors affecting the distribution of zooplankton communities}

Most environmental parameters strongly correlated with temperature and showed large differences between the epilimnion and colder water layers. The temperature was positively correlated with: $\mathrm{pH}(\mathrm{r}=0.69 ; \mathrm{P}<0.0001)$, dissolved oxygen $(\mathrm{r}=0.80 ; \mathrm{P}<0.0001)$, TOC $(\mathrm{r}=0.86$; $\mathrm{P}<0.0001)$ and DOC $(\mathrm{r}=0.83 ; \mathrm{p}<0.0001)$. Additionally, temperature was negatively correlated with: $\mathrm{TN}(\mathrm{r}=-0.67$; $\mathrm{P}<0.0001), \mathrm{DN} \quad(\mathrm{r}=-0.60 ; \mathrm{P}=0.0002), \mathrm{NO}_{3}^{-} \quad(\mathrm{r}=-0.41$; $\mathrm{P}=0.015)$, IC $(\mathrm{r}=-0.57 ; \mathrm{P}=0.001)$ and $\mathrm{PO}_{4}{ }^{3-}(\mathrm{r}=-0.36$; $\mathrm{P}=0.036)$. A Canonical Correspondence Analysis (CCA) was performed to identify combinations of abiotic (temperature, oxygen, nutrients) and biotic (phytoplankton) factors that affect the community structure of zooplankton. The most important environmental predictors that explain the community structure of zooplankton were temperature, electrical conductivity and oxygen concentrations (Tab. 4). The first axis of the CCA ordinations was the most important, explaining the distribution of the dominant zooplankton

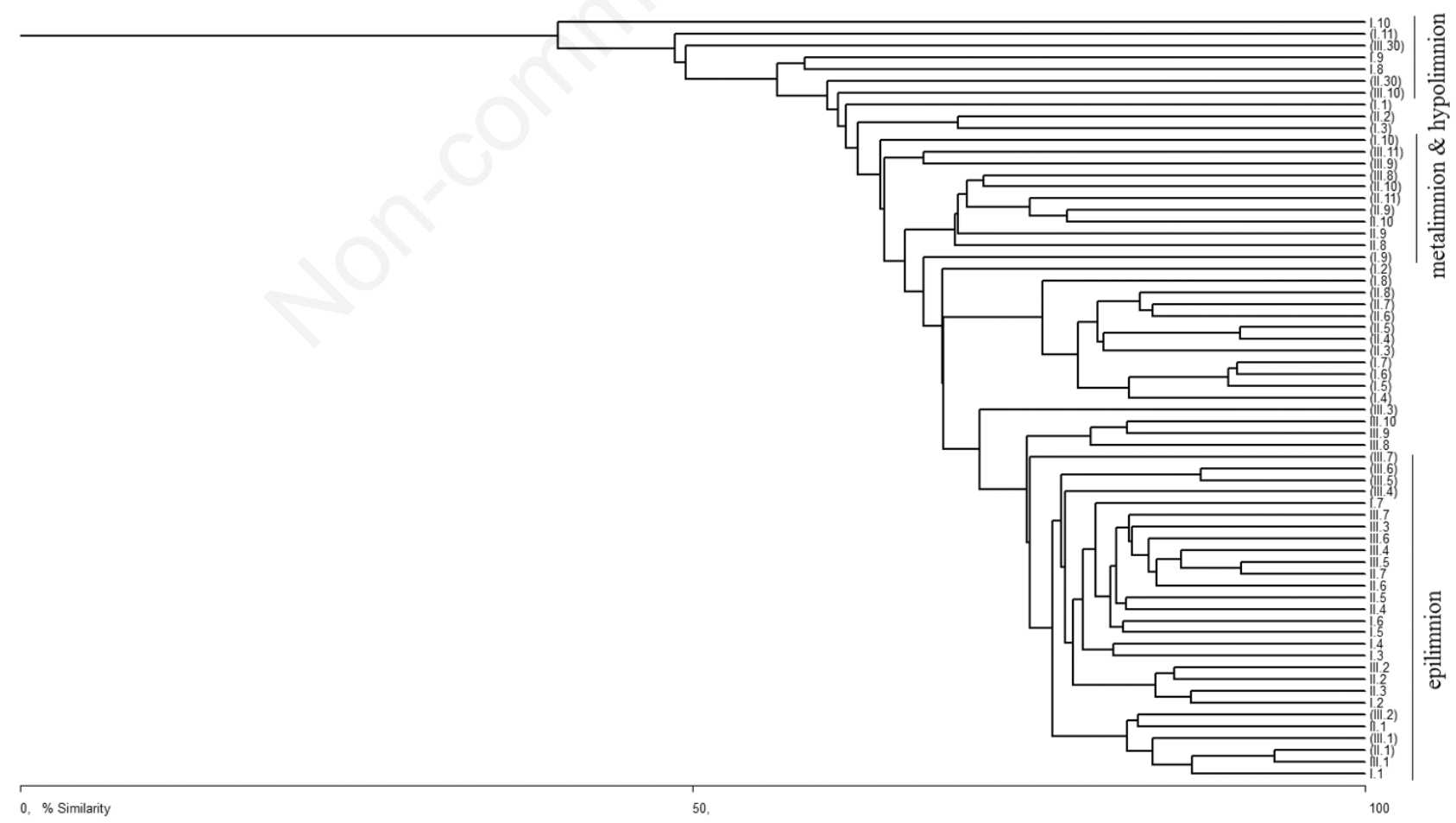

Fig. 6. The Bray-Curtis similarity matrix of crustacean zooplankton assemblages between all study sites based on the agglomerative hierarchical cluster analysis (AHC). The code for stations: Roman numerals (I, II, III) represents different stations (as in Tab. 1); the numbers $(1-11,30)$ are depth $(\mathrm{m})$; sampling stations in 2016 are in parentheses. 
species (Fig. 7). The temperature was strongly related to the first axis, with the highest regression coefficient (negatively correlated), and a very low regression coefficient to the second axis (Tab. 4). Most epilimnion stations were negatively correlated with the first axis, while hypolimnion stations were strongly and positively correlated with the first axis of the CCA analysis. Eurytemora lacustris and Asplanchna priodonta were strongly related to low temperatures (Fig. 7), with Daphnia cristata also being associated with lower temperatures and lower oxygen concentrations (Fig. 7). Small crustaceans and Keratella cochlearis tecta, Gastropus stylifer and Ascomorpha ovalis seem to prefer higher temperatures (Fig. 7). The D. cucullata biomass appears less sensitive to environmental parameters than any other species (Fig. 7). This decrease in sensitivity could be the result of the vertical differences in both the Daphnia cucullata body size and abundance (Fig. 5). The abundance of $D$. cucullata (ind. $\mathrm{L}^{-1}$ ) was positively correlated with temperature $(r=0.67 ; \mathrm{P}<0.0001)$, while the body size of $D$. cucullata was negatively correlated with temperature $(\mathrm{r}=-0.42 ; \mathrm{P}=0.013)$. The well-oxygenated hypolimnion results in a large diversity of Daphnia species, where $D$. longiremis, D. cristata and $D$. longispina were all found. Both the physicochemical parameters and phytoplankton explained $63 \%, 46 \%, 32 \%$

Tab. 4. The regression coefficient for the CCA axis (F1 and F2) to the environmental predictors affecting the community structure of zooplankton.

\begin{tabular}{ccccccccccccc} 
& $\mathrm{EC}$ & $\mathrm{temp}$ & $\mathrm{O}_{2}$ & $\mathrm{PO}_{4}{ }^{3-}$ & $\mathrm{DOC}$ & $\mathrm{IC}$ & $\mathrm{TN}$ & $\mathrm{GI}$ & GII & GIII & GIV \\
$\mathrm{F} 1$ & 0.46 & -1.26 & 0.33 & 0.14 & 0.09 & -0.41 & 0.01 & 0.05 & -0.04 & -0.3 & -0.18 \\
\hline $\mathrm{F} 2$ & 0.68 & -0.02 & 0.51 & 0.02 & -0.31 & -1.02 & 0.2 & -0.04 & 0.39 & -0.2 & 0.11
\end{tabular}

EC, electrical conductivity; DOC, dissolved organic carbon; IC, inorganic carbon; TN, total nitrogen; GI, Chlorophyta and Euglenophyta; GII, Heterokontophyta, Haptophyta, and Dinophyta; GIII, Cryptophyta; GIV, Cyanophyta.

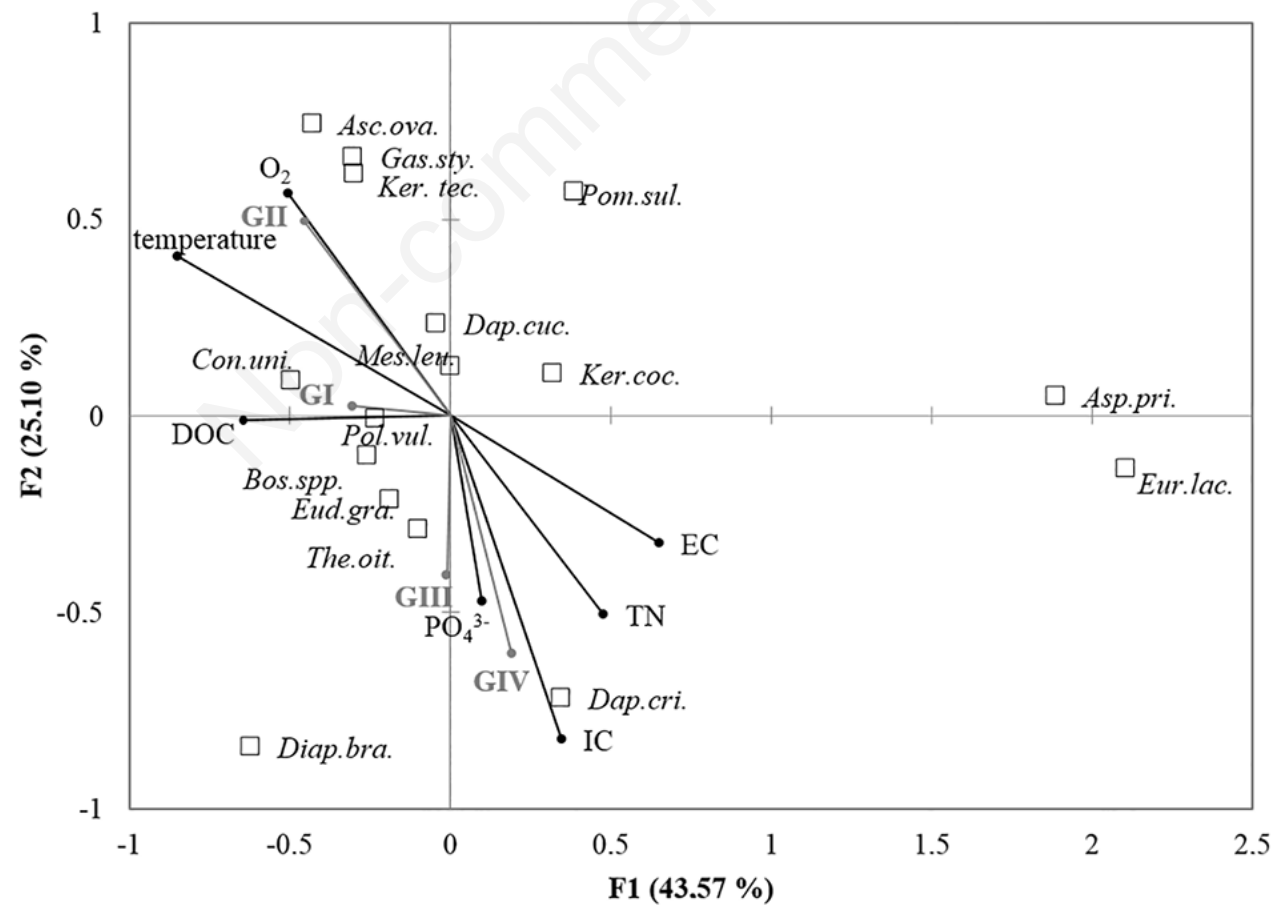

Fig. 7. Relations between the abundance of dominant zooplankton species to the environmental variables (hydrochemistry and phytoplankton) visualised by the Canonical Correspondence Analysis map. Abbreviations of environmental variables are in Tab. 4. The taxa shown are Dap.cuc. - Daphnia cucullata. Dap.cri. - Daphnia cristata. Dia.bra. - Diaphanosoma brachyurum. Bos.spp. - Bosmina species. Eud.gra. - Eudiaptomus graciloides. Eur.lac. - Eurytemora lacustris. The.oit. - Thermocyclops oithonoides. Mes.leu. - Mesocyclops leuckarti. Asp.pri - Asplanchna priodonta. Pol.vul. - Polyarthra vulgaris. Con.uni. - Conochilus unicornis. Ker.coc. - Keratella cochlearis. Ker.tec. - Keratella tecta. Gas.sty. - Gastropus stylifer. Asc.ova. - Ascomorpha ovalis. Pom.sul. - Pompholyx sulcata. 
and $40 \%$ of the variability of D. cristata, D. cucullata, D. longispina and $D$. longiremis, respectively. The most important environmental parameters, which explained the abundance of $D$. cristata, were: oxygen $(\mathrm{F}=15.49$; $\mathrm{P}=0.0003)$, cyanobacteria $(\mathrm{F}=12.13 ; \mathrm{P}=0.001), \quad \mathrm{TN}$ $(\mathrm{F}=6.93 ; \mathrm{p}=0.011)$, DOC $(\mathrm{F}=5.74 ; \mathrm{P}=0.021)$ and $\mathrm{IC}$ $(\mathrm{F}=4.53 ; \mathrm{P}=0.039)$. The biomass of $D$. cucullata was related to the concentration of $\mathrm{NH}_{4}^{+}(\mathrm{F}=5.97 ; \mathrm{P}=0.018)$ and $\mathrm{NO}_{3}{ }^{-}(\mathrm{F}=5.6 ; \mathrm{P}=0.022)$, while $D$. longispina was related only to oxygen concentration $(\mathrm{F}=8.06 ; \mathrm{P}=0.007)$. The distribution of $D$. longiremis was not explained by the ANCOVA model.

The comparison of zooplankton communities in vertical profiles of three stations revealed that the vertical gradient in the water profile is much more important for microcrustaceans than the horizontal changes in environmental conditions. There was a notably high similarity of microcrustaceans in the epilimnion zones of different stations for both years (Fig. 6). A slightly lower similarity of crustacean communities was found in the lower water layers (metalimnion and hypolimnion) of the different stations in both years (Fig. 6). The Rotifera showed a strong horizontal autocorrelation connected with the differences in trophic status. The AHC analysis revealed differences in Rotifera communities between shallow station I and the deep basins (Fig. 8). In the case of Rotifera, an annual pattern is also visible (Fig. 8). According to the Mantel test, rotifer $(\mathrm{r}=0.82 ; \mathrm{P}<0.0001)$ and crustacean $(\mathrm{r}=0.86 ; \mathrm{P}<0.0001)$ communities showed significant concordance in their assemblage patterns for both years.

\section{DISCUSSION}

There are many different monitoring strategies, ranging from long-term time-series in individual lakes to short-term snapshot surveys of many lakes from disparate locations. These strategies serve different purposes and cover different temporal and spatial scales of ecological phenomena (Mantzouki et al., 2018). For example, plankton dynamics can be driven by long-term environmental change (Monchamp et al., 2016), interannual variability (Anneville et al., 2004), seasonal succession (Sommer et al., 2012) and diel changes (Ibelings et al., 1991). To efficiently capture a combination of many factors that influence the threedimensional distribution patterns of rotifer and crustacean communities in a pelagic environment, we decided to create a snapshot survey in one lake with diversified morphometry and trophic conditions. We conducted this

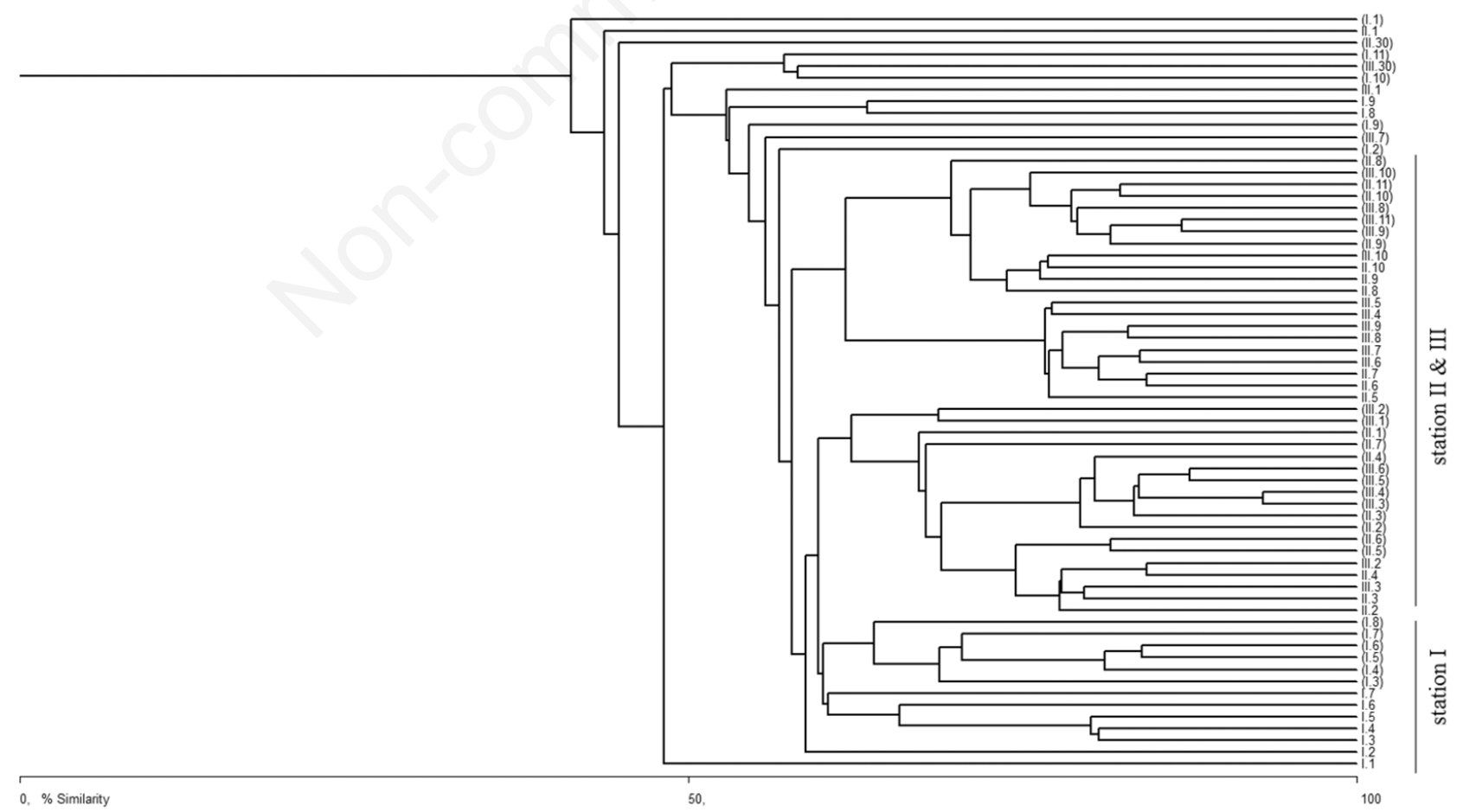

Fig. 8. The Bray-Curtis similarity matrix of Rotifera assemblages between all study sites based on the agglomerative hierarchical cluster analysis (AHC). The code for stations: Roman numerals (I, II, III) represent different stations (as in Tab. 1); numbers (1-11, 30) are depths (m); and sampling stations in 2016 are in parentheses. 
research at three different sampling stations in the middle of the summer stagnation over two years at the same time of the day (midday).

The comparison of abiotic and biotic factors that influence the spatial distribution of zooplankton revealed differences in the case of Rotifera and Crustacea. The results of our study indicate that the vertical gradient in the water profile is much more important for the microcrustaceans than the horizontal changes in environmental conditions. At the same time, Rotifera showed strong horizontal autocorrelations that were connected with differences in trophic status. The rotifer species, being opportunistic, exhibit high rates of increase and short life cycles and may respond concurrently to environmental changes. The variations in rotifer abundance and composition of species between lakes are mainly regulated by "bottom-up" forces as opposed to "top-down" predatory interactions. Therefore, rotifers are widely used as indicators of the quality of lake ecosystems (Yoshida et al., 2003; Ejsmont-Karabin, 2012). We have found differences in Rotifera communities between three stations on Lake Wigry, which could be related to the differences in trophic conditions. Each part of Lake Wigry has its own unique morphometry and water exchange, leading to different habitat conditions (Kamiński, 1999). In the case of Rotifera, even the annual pattern was visible in response to the different environmental conditions of each year. However, rotifers showed a relatively uniform distribution throughout the water column of Lake Wigry. This result is common for eutrophic lakes, and is a phenomenon of a homogeneous distribution of rotifer species in the water column (Stewart and George, 1987; De Paggi, 1995). Some authors believe that vertical migrations are less important in rotifers than in other groups of plankton invertebrates, and the range of the migration is a function of animal body size (George and Fernando, 1970). On the other hand, a decrease in rotifer numbers in the layer with the presence of larger Daphnia may be a result of their suppression by Daphnia, which could suppress both small and large rotifers due to the combined effects of interference (small rotifers) and exploitative competition (large ones) (Gilbert, 1988). Such suppression has not been observed in our studies. The reason for the lack of suppression may be the dominance of large colonies of two Conochilus species. The large size of the colonies and their gelatinous sheets is potentially a good defence against invertebrate predators. Therefore, there is a suppression of these species by Daphnia in fishless lakes (Drouin et al., 2009); however, in the presence of fish, the large colonies of Conochilus species become hazardous. As a result, there are many factors that play a role in Conochilus dominance in the epilimnion at stations I and II, rendering it rather difficult to explain.
The zooplankton of Lake Wigry is dominated by large Daphnia, which is susceptible to visual predation (Carpenter et al., 1985). The high densities of planktivorous fish in Lake Wigry did not result in a shift to the smaller zooplankton species. On the contrary, we observed a large diversity of the Daphnia genus. The behaviour of Daphnia is of special importance in freshwater systems not only because their populations have a strong top-down effect on primary production but also because they are a critical food source that supports higher trophic levels (Carpenter et al., 2001; Pace et al., 2004). Diel vertical migration in zooplankton has a long history in limnology research, which has traditionally focused on the mechanisms driving this behaviour (Stich and Lampert, 1981). The most cited driver of diel vertical migration is the avoidance of visual predators by migration to dark waters during the day, and returning to food-rich epilimnetic waters at night to access the phytoplankton (Zaret and Suffern, 1976; Carpenter and Kitchell, 1993). However, some studies suggest that most zooplankton taxa had similar depth distributions during the night and at day, indicating a lack of diel vertical migration behaviour on a large scale (Bernot et al., 2004). Despite the diel vertical migrations, most results suggest that the daytime mean residence depth of Daphnia species is relatively stable (Brosseau et al., 2012). Our results confirm the similar mean daytime residence depth of different Daphnia species in different parts of the lake over both years. Lake Wigry is a great example of the vertical niche segregation by the Daphnia species. D. cucullata strongly dominated the zooplankton communities in the epilimnion zones of Lake Wigry. This species is less influenced by the fish pressure because it is completely colourless, and often dominates in European lakes where fish predation is intense (Błędzki and Rybak, 2016). However, D. cristata and D. longispina prefer the metalimnion and upper hypolimnion, whereas $D$. longiremis and $D$. hyalina (recently revised as D. longispina; Benzie, 2005; Petrusek et al., 2008) were found in deep waters. Different species within the $D$. longispina complex could occupy different niches, as they differ from each other with regard to life-history strategies, habitat preferences, behaviour, morphology, body size, filtration rate and vulnerability to predation (Brzeziński et al., 2012). Similarly, two competing species of Daphnia in a stratified natural lake segregate themselves along a depth gradient according to their relative susceptibility to predators (Leibold and Tessier, 1991).

The most important factor influencing the distribution of planktonic crustaceans in Lake Wigry was a vertical gradient of environmental conditions. Lake Wigry has a relative calm pelagic zone and the gradual decrease of water temperature from the surface shows an epilimnion 
with almost no mixing. These conditions are ideal for testing the impact of environmental vertical gradient on plankton communities because they exclude windinduced circulations. A sharp gradient of temperature in the metalimnion results in large differences in environment conditions, i.e. increased electrical conductivity and nutrient concentrations, with the lowest oxygen concentrations. These nutrient-rich waters of the metalimnion may play an important role in the vertical distribution of phytoplankton. The increased algal density below the thermocline is a common phenomenon in both oligotrophic and mesotrophic lakes, which is related to nutrient availability (Fasham et al., 1985; Fee et al., 1996; Camacho, 2006). The low trophic conditions associated with vertical stratification promote epilimnetic summer nutrient depletion and allow sufficient light to penetrate the lower water layer (Reynolds, 1992). The study of unpolluted lakes in Suwalki Landscape Park revealed that maximum concentrations of phytoplankton in the hypolimnion zones were up to 15 times higher than in the epilimnion zone (Karpowicz et al., 2016; Karpowicz and Ejsmont-Karabin, 2017). However, the maximum concentrations of phytoplankton in the epilimnion are typical for eutrophic lakes without epilimnetic summer nutrient depletion. This study demonstrates similar results in the deep basins of Lake Wigry, where the highest concentrations of phytoplankton were found in the middle of the epilimnion. These food resources strongly influence the vertical distribution of Daphnia cucullata, a dominant zooplankton species. Our results support the hypothesis that Daphnia choose their habitat according to an Ideal Free Distribution with Costs model in order to optimise their fitness in response to the food and temperature conditions (Lampert and Grey, 2003). Moreover, we found that larger individuals of Daphnia cucullata prefer the thermocline zone, despite the lower concentration of phytoplankton there. This finding suggests that large individuals may avoid visual predators by migration to dark waters during the day, while the smaller individuals of Daphnia cucullata clearly prefer warm surface waters. The environmental factors that are important in explaining the community structure of zooplankton are temperature, oxygen concentrations and electrical conductivity. Generally, large-size species dominated in colder water layers of Lake Wigry, whereas smaller species preferred the warm epilimnion. The migration of large zooplankton to deeper waters creates favourable conditions for smaller species in the epilimnion (Karpowicz and EjsmontKarabin, 2017). This finding could be the reason for high diversity in zooplankton at Lake Wigry. The welloxygenated water of the hypolimnion zone creates a favourable habitat for large Daphnia and for the species with high environmental requirements. The high species diversity of pelagic zooplankton gives a very specific value to Lake Wigry, particularly due to the occurrence of the relict and rare species of crustaceans: D. longiremis, Eurytemora lacustris and Heterocope appendiculata (Kamiński, 1999; Karpowicz and Górniak, 2013). D. longiremis is a cold stenotherm species complex with a limited distribution in Europe and is primarily reported from the hypolimnion of large and deep lakes and from creeks and ponds in arctic areas (Błędzki and Rybak, 2016). Another stenotherm species, Eurytemora lacustris, is rare and endangered as a result of eutrophication, oxygen condition deterioration and global warming (Kasprzak et al., 2005; Maier et al., 2011; Karpowicz and Kalinowska, 2018). The intense eutrophication and deterioration of oxygen conditions in the second half of the twentieth century caused E. lacustris to occasionally appear in Lake Wigry (Karabin and Ejsmont-Karabin, 1992). After a significant reduction of the phosphorus load from the catchment and biomanipulation at the end of the twentieth century, water quality radically improved (Kamiński, 1999). The results of our study revealed a high density of E. lacustris, up to 8 ind. $\mathrm{L}^{-1}$ in cold waters of the metalimnion-hypolimnion. The literature data suggest that the maximum abundance of the E. lacustris population is seen in the winter, with a maximum of ca. 8 ind. $\mathrm{L}^{-1}$ (Weiler et al., 2003). These findings suggest that there are improving conditions in Lake Wigry. Additionally, our results confirm that the previous findings of the high abundance of E. lacustris in the thermocline zone show that this species can temporarily tolerate lower oxygen concentrations due to the better food resources in the thermocline (Karpowicz and Kalinowska, 2018).

\section{CONCLUSIONS}

The results of our study demonstrate that zooplankton communities are very susceptible to changes in environmental conditions. The Rotifera were more sensitive to changes in trophic conditions, while the distribution of planktonic microcrustaceans was determined by the vertical gradient of temperature in the water column. The well-oxygenated hypolimnion zone promotes a large diversity of crustacean zooplankton due to vertical niche segregation. Alongside the vertical and horizontal differences in environmental conditions, there was also an annual difference. In 2016, we observed a lower abundance of phytoplankton, greater water transparency and higher oxygen concentration in the metalimnion. Better environmental conditions in 2016 resulted in more diverse crustacean communities and a lower biomass of Rotifera. Both a decreased crustacean species diversity and an increased abundance of Rotifera are common symptoms of eutrophication (Andronikova, 1996; Ejsmont-Karabin, 2012). In this case, the crustacean 
communities were relatively stable on a temporal and spatial scale, and the same dominant species were found in similar proportions at all sampling stations. Rotifer communities respond more adequately to the changes in environmental conditions, and there were large differences in biomass, species composition, and domination.

\section{ACKNOWLEDGMENTS}

The authors are thankful to the employees of the Wigry National Park for their help in the collection of samples and to Helena Samsonowicz for her assistance in the water chemistry analyses.

\section{REFERENCES}

Andronikova I, 1996. Zooplankton characteristics in monitoring of Lake Ladoga. Hydrobiologia 322:173-179.

Angeli N, Pinel-Alloul B, Balvay G, Ménard I, 1995. Diel patterns of feeding and vertical migration in daphnids and diaptomids during the clear water phase in Lake Geneva (France), p. 163-184. In: G. Balvay (ed.), Space partition within aquatic ecosystems. Springer, Dordrecht.

Anneville O, Souissi S, Gammeter S, Straile D, 2004. Seasonal and inter-annual scales of variability in phytoplankton assemblages, comparison of phytoplankton dynamics in three peri-alpine lakes over a period of 28 years. Freshwater Biol. 49:98-115.

APHA, 2001. Standard methods for the examination of water and wastewater. 21 st ed. APHA-AWWA-WEF, Washington DC, USA.

Bartrons M, Einarsson A, Nobre RLG, Herren CM, Webert KC, Brucet S, Olafsdottir SR, Ives AR, 2015. Spatial patterns reveal strong abiotic and biotic drivers of zooplankton community composition in Lake Mývatn, Iceland. Ecosphere 6:105.

Bays JS, Crisman TL, 1983. Zooplankton and trophic state relationships in Florida lakes. Can. J. Fish. Aquat. Sci. 40:1813-1819.

Benzie JAH, 2005. Cladocera: The genus Daphnia (including Daphniopsis). Backhuys Publishers, Leiden.

Bernot RJ, Dodds WK, Quist MC, Guy CS, 2004. Spatial and temporal variability of zooplankton in a Great Plains Reservoir. Hydrobiologia 525:101-112.

Beutler M, Wiltshire KH, Meyer B, Moldaenke C, Lüring C, Meyerhöfer M, Hansen U-P, Dau H, 2002. A fluorometric method for the differentiation of algal populations in vivo and in situ. Photosyn. Res. 72:39-53.

Błędzki LA, Rybak JI, 2016. Freshwater crustacean zooplankton of Europe. Springer, Berlin.

Brooks JL, Dodson SL, 1965. Predation, body-size, and composition of plankton. Science 150:28-35.

Brosseau CJ, Cline TJ, Cole JJ, Hodgson JR, Pace ML, Weidel BC, 2012. Do Daphnia use metalimnetic organic matter in a north temperate lake? An analysis of vertical migration. Inland Waters 2:193-198.
Brown JS, 1990. Habitat selection as an evolutionary game. Evolution 44:732-746.

Brzeziński T, Fronk J, Trzcińska-Danielewicz J, Dawidowicz P, 2012. Interspecific hybridization in sympatric species of Daphnia inhabiting lakes in north-eastern Poland. Oceanol. Hydrobiol. Stud. 41:1-6.

Camacho A, 2006. On the occurrence and ecological features of deep chlorophyll maxima (DCM) in Spanish stratified lakes. Limnetica 25:453-478.

Cantin A, Beisner BE, Gunn JM, Prairie YT, Winter JG, 2011. Effects of thermocline deepening on lake plankton communities. Can. J. Fish. Aquat. Sci. 68:260-276.

Carpenter SR, 1988. Complex interactions in lake communities. Springer-Verlag, Berlin.

Carpenter SR, Cole JJ, Hodgson JR, Kitchell JF, Pace ML, Bade D, Cottingham KL, Essington TE, Houser JN, Schindler DE, 2001. Trophic cascades, nutrients, and lake productivity: whole-lake experiments. Ecol. Monogr. 71:163-186.

Carpenter SR, Kitchell JF, 1993. The Trophic Cascade in Lakes. Cambridge (UK), Cambridge University Press.

Carpenter SR, Kitchell JF, Hodgson JR, 1985. Cascading trophic interactions and lake productivity. BioScience 35:634-639.

Cole PC, Luecke C, Wurstbaugh WA, Burkart G, 2002. Growth and survival of Daphnia in epilimnetic and metalimnetic water from oligotrophic lakes: the effects of food and temperature. Freshwater Biol. 47:2113-2122.

De Paggi SJ, 1995. Vertical distribution and diel migration of rotifers in a Parana River floodplain lake. Hydrobiologia 310:87-94.

Drouin A, Sirois P, Archambault Ph, 2009. Discriminating zooplankton communities in lakes with brook trout (Salvelinus fontinalis) and in fishless lakes. Ecoscience 16:271-281

Ejsmont-Karabin J, 1998. Empirical equations for biomass calculation of planktonic rotifers. Pol. Arch. Hydrobiol. 45:513-522.

Ejsmont-Karabin J, 2012. The usefulness of zooplankton as lake ecosystem indicators: Rotifer Trophic State Index. Pol. J. Ecol. 60:339-350.

Fasham MJR, Platt T, Irwin B, Jones K, 1985. Factors affecting the spatial pattern of the deep chlorophyll maximum in the region of the Azores front. Prog. Oceanogr. 14:129-165.

Fee EJ, Hecky RE, Kasian SEM, Cruikshank DR, 1996. Effects of lake size, water clarity, and climatic variability on mixing depths in Canadian Shield lakes. Limnol. Oceanogr. 41:912-920.

Ferrão-Filho ADS, Kozlowsky-Suzuki B, 2011. Cyanotoxins: Bioaccumulation and effects on aquatic animals. Mar. Drugs 9:2729-2772.

Fietz S, Kobanova G, Izmesteva L, Nicklisch A, 2005. Regional, vertical and seasonal distribution of phytoplankton and photosynthetic pigments in Lake Baikal. J. Plankton Res. 27:793-810.

Folt CL, Burns CW, 1999. Biological drivers of zooplankton patchiness. Trends Ecol. Evol. 14:300-305.

Fussmann G, 1996. The importance of crustacean zooplankton in structuring rotifer and phytoplankton communities: an enclosure study. J. Plankton Res. 18:1897-1915.

George DG, Winfield IJ, 2000. Factors influencing the spatial 
distribution of zooplankton and fish in Loch Ness, UK. Freshwater Biol. 43:557-570.

George MG, Fernando CH, 1970. Diurnal migration in three species of rotifers in Sunfish Lake, Ontario. Limnol. Oceanogr. 15:218-223.

Gilbert JJ, 1985. Competition between rotifers and Daphnia. Ecology 66:1943-1950.

Gilbert JJ, 1988. Susceptibilities of ten rotifer species to interference from Daphnia pulex. Ecology 69:1826-1838.

Gilbert JJ, 1989. The effect of Daphnia interference on a natural rotifer and ciliate community: short-term bottle experiments. Limnol. Oceanogr. 34:606-617.

Gliwicz ZM, 1979. Metalimnetic gradients and trophic state of lake epilimnia. In: R. de Bernardi (ed.), Proc. Symp. Biological and Mathematical aspects in population dynamics. Mem. Ist. ital. Idrobiol. Suppl. 37:121-143.

Gliwicz ZM, 1980. Metalimnetic gradients and phosphorus loss from the epilimnion in stratified eutrophic lakes, p. 23-27. In: J. Barica and L.R. Mur (eds.) Hypertrophic Ecosystems. Springer, Dordrecht.

Gliwicz ZM, 1990. Why do Cladocerans fail to control algal blooms? Hydrobiologia 200:83-97.

Gregor J, Marsálek B, 2004. Freshwater phytoplankton quantification by chlorophyll $a$ : a comparative study of in vitro, in vivo and in situ methods. Water Res. 38:517-522.

Harrison JW, Howell ET, Watson SB, Smith REH, 2016. Improved estimates of phytoplankton community composition based on in situ spectral fluorescence: use of ordination and field-derived norm spectra for the bbe FluoroProbe. Can. J. Fish. Aquat. Sci. 73:1472-1482.

Ibelings B, Mur L, Kinsman R, Walsby A, 1991. Microcystis changes its buoyancy in response to the average irradiance in the surface mixed layer. Arch. Hydrobiol. 120:385-401.

Jeppesen E, Søndergaard M, Jensen JP, Havens K, Anneville O, Carvalho L, Coveney MF, Deneke R, Dokulil M, Foy B, Gerdeaux D, Hampton SE, Kangur K, Köhler J, Körner S, Lammens E, Lauridsen TL, Manca M, Miracle R, Moss B, Nõges P, Persson G, Phillips G, Portielje R, Romo S, Schelske CL, Straile D, Tatrai I, Willén E, Winder M, 2005. Lake responses to reduced nutrient loading — an analysis of contemporary long-term data from 35 case studies. Freshwater Biol. 50:1747-1771.

Kamiński M, 1999. Lake Wigry, the lake "adopted" by international association of theoretical and applied limnology (SIL “Lake Adoption” Project). Pol. J. Ecol. 47:215-224.

Karabin A, Ejsmont-Karabin J, 1992. [Zooplankton of Lake Wigry], p. 101-113. In: B. Zdanowski (ed.) [Lakes of the Suwałki Landscape Park. State of eutrophication and measures of protection].[Book in Polish]. Zakl. Nar. im. Ossolińskich, Wyd. PAN, Wrocław-Warszawa-Kraków.

Karpowicz M, Ejsmont-Karabin J, 2017. Effect of metalimnetic gradient on phytoplankton and zooplankton (Rotifera, Crustacea) communities in different trophic conditions. Environ. Monit. Assess. 189:367.

Karpowicz M, Ejsmont-Karabin J, 2018. Influence of environmental factors on vertical distribution of zooplankton communities in humic lakes. Ann. Limnol. Int. J. Lim. 54:17.

Karpowicz M, Górniak A, 2013. [Crustacean zooplankton of harmonious lakes in Wigry National Park and relationship with the trophic state].[Article in Polish with English Abstract]. Monitoring Środowiska Przyrodniczego 14:97-101.

Karpowicz M, Górniak A, Więcko A, Cudowski A, 2016. The variability of summer phytoplankton in different types of lakes in North East Poland (Suwałki Landscape Park). Limnol. Rev. 16:229-236.

Karpowicz M, Kalinowska K, 2018. Vertical distribution of the relic species Eurytemora lacustris (Copepoda, Calanoida) in stratified mesotrophic lakes. Biologia 73:1197-1204.

Kasprzak P, Reese C, Koschel R, Schulz M, Hambaryan I, Mathes J, 2005. Habitat characteristics of Eurytemora lacustris (Poppe, 1887) (Copepoda, Calanoida): The role of lake depth, temperature, oxygen concentration and light intensity. Int. Rev. Hydrobiol. 90:292-309.

Korhonen JJ, Köngäs P, Soininen J, 2013. Temporal variation of diatom assemblages in oligotrophic and eutrophic streams. Eur. J. Phycol. 48:2:141-151.

Lacroix G, Lescher-Moutoué F, 1995. Spatial patterns of planktonic microcrustaceans in a small shallow lake. Hydrobiologia 300/301:205-217.

Lampert W, 1993. Ultimate causes of diel vertical migration of zooplankton: New evidence for the predator avoidance hypothesis. Arch. Hydrobiol.-Beih. Ergebn. Limnol. 39:70-88.

Lampert W, Grey J, 2003. Exploitation of deep-water algal maximum by Daphnia: a stable-isotope tracer study. Hydrobiologia 500:95-101.

Leibold MA, Tessier AJ, 1991. Contrasting patterns of body size for coexisting Daphnia species that segregate by habitat. Oecologia 86:342-348.

Lima SL, 1998. Nonlethal effects in the ecology of predator prey interactions. Bioscience 48:25-34.

Maier G, Speth B, Wolfgang ARP, Bahnwart M, Kasprzak P, 2011. New records of the rare glacial relict Eurytemora lacustris (Poppe 1887) (Copepoda; Calanoida) in atypical lake habitats of northern Germany. J. Limnol. 70:145-148.

Mantzouki E, Beklioglu M, Brookes JD, de Senerpont Domis LN, Dugan HA, Doubek JP, Grossart H-P, Nejstgaard JC, Pollard AI, Ptacnik R, Rose KC, Sadro S, Seelen L, Skaff NK, Teubner K, Weyhenmeyer GA, Ibelings BW, 2018. Snapshot surveys for lake monitoring, more than a shot in the dark. Front. Ecol. Evol. 6:201.

Monchamp M-E, Walser J-C, Pomati F, Spaak P, 2016. Sedimentary DNA reveals cyanobacteria community diversity over 200 years in two peri-alpine lakes. Appl. Environ. Microbiol. 82:6472-6482.

Pace ML, 1986. An empirical analysis of zooplankton community size structure across lake trophic gradients. Limnol. Oceanogr. 31:45-55.

Pace ML, Cole JJ, Carpenter SR, Kitchell JF, 1999. Trophic cascades revealed in diverse ecosystems. Trends Ecol. Evol. 14:483-488.

Pace ML, Cole JJ, Carpenter SR, Kitchell JF, Hodgson JR, Van de Bogert MC, Bade DL, Kritzberg ES, Bastviken D, 2004. Whole-lake carbon-13 additions reveal terrestrial support of aquatic food webs. Nature 427:240-243.

Patalas K, Salki A, 1992. Crustacean plankton in Lake Winnipeg - variation in space and time as a function of lake morphology, geology, and climate. Can. J. Fish. Aquat. Sci. 49:1035-1059.

Petrusek A, Seda J, Machácek J, Ruthová S, Smilauer P, 2008. 
Daphnia hybridization along ecological gradients in pelagic environments: the potential for the presence of hybrid zones in plankton. Philos. T. Roy. Soc. B 363:2931-2941.

Pinel-Alloul B, 1995. Spatial heterogeneity as a multi-scale characteristic of zooplankton community. Hydrobiologia 300:17-42.

Pinel-Alloul B, Ghadouani A, 2007. Spatial heterogeneity of planktonic microorganisms in aquatic systems, p. 203-310. In: R.B. Franklin and A.L. Mills (eds.), The spatial distribution of microbes in the environment. Springer, Dordrecht

Pothoven SA, Fahnenstiel GL, Vanderploeg HA, 2004. Spatial distribution, biomass and population dynamics of Mysis relicta in Lake Michigan. Hydrobiologia 522:291-299.

Reynolds CS, 1992. Dynamics, selection and composition of phytoplankton in relation to vertical structure in lakes. Arch. Hydrobiol. Beih. Ergebn. Limnol 35:13-31.

Rinke KH, Huber AMR, Kempke S, Eder M, Wolf T, Probst WN, Rothhaupta K-O, 2009. Lake-wide distributions of temperature, phytoplankton, zooplankton, and fish in the pelagic zone of a large lake. Limnol. Oceanogr. 54:1306-1322.

Rosenzweig ML, 1991. Habitat selection and population interactions: the search for mechanism. Am. Nat. 137:385-387.

Sługocki Ł, Czerniawski R, 2018. Trophic state $\left(\mathrm{TSI}_{\mathrm{SD}}\right)$ and mixing type significantly influence pelagic zooplankton biodiversity in temperate lakes (NW Poland). PeerJ 6:e5731.

Sommer U, Adrian R, de Senerpont Domis L, Elser JJ, Gaedke U, Ibelings WB, Jeppesen E, Lürling M, Molinero JC, Mooij WM, van Donk E, Winder M, 2012. Beyond the Plankton Ecology Group (PEG) model: mechanisms driving plankton succession. Annu. Rev. Ecol. Evol. Syst. 43:429-448.

Stewart LJ, George DG, 1987. Environmental factors influencing the vertical migration of planktonic rotifers in a hypereutrophic tarn. Hydrobiologia 147:203-208.

Stich HB, Lampert W, 1981. Predator evasion as an explanation of diurnal vertical migration by zooplankton. Nature 293:396-298.

ter Braak CJF, 1986. Canonical correspondence analysis: a new eigenvector technique for multivariate direct gradient analysis. Ecology 67:1167-1179.

Thackeray SJ, George GD, Jones RJ, Winfield IJ, 2004. Quantitative analysis of the importance of wind-induced circulation for the spatial structuring of planktonic populations. Freshwater Biol. 49:1091-1102.

Tyler JA, Gilliam JF, 1995. Ideal free distributions of stream fish: a model and test with minnows, Rhinicthys atratulus. Ecology 76:580-592.

Weiler W, Kasprzak P, Schulz M, Flössner D, 2003. Habitat requirements of Eurytemora lacustris (Copepoda, Calanoida) and implications for its distribution. Arch. Hydrobiol. 58:203-214.

Whittaker RH, 1956. Vegetation of the Great Smoky Mountains. Ecol. Monogr. 26:1-80.

Winder M, Buergi HR, Spaak P, 2003. Seasonal vertical distribution of phytoplankton and copepod species in a highmountain lake. Arch. Hydrobiol. 158:197-213.

Yoshida T, Urabe J, Elser J, 2003. Assessment of "top-down" and "bottom-up" forces as determinants of rotifer distribution among lakes in Ontario, Canada. Ecol. Res. 18:639-665.

Zaret TM, Suffern JS, 1976. Vertical migration in zooplankton as a predator avoidance mechanism. Limnol. Oceanogr. 21:804-813. 